Proceedings

\title{
Share and Communicate the Cento Città d'Italia: From the XIX to the XXI Century ${ }^{\dagger}$
}

\author{
Ursula Zich * and Martino Pavignano \\ Politecnico di Torino, Dipartimento di Architettura e Design, 10125 Torino, Italy; \\ martino.pavignano@polito.it \\ * Correspondence: ursula.zich@polito.it; Tel.: +39-011-0904364 \\ + Presented at the International and Interdisciplinary Conference IMMAGINI? Image and Imagination \\ between Representation, Communication, Education and Psychology, Brixen, Italy, 27-28 November 2017.
}

Published: 16 November 2017

\begin{abstract}
The European cultural context, where the series Le Cento Città d'Italia-Supplemento mensile illustrato del Secolo (Milan, Sonzogno 1887-1902) can be situated, has been characterized by a great diffusion of publications based on illustrated issues. This series, which led readers to 'literary' and 'visually' "visit the most important (for history, art and architecture) Italian cities", provides interesting views and sketches of the post-unification Italy. Relying on this amount of unstudied information offered by Le Cento Città, and taking in account other similar project, this paper aims to describe the issues and the very first outcomes of our work of designing an Territorial Information System (SIT) that will allow a textual, graphical and crossed 'navigation' through these sources. Open to new contributions, the SIT will level up the experience of interconnecting texts and images with georeferenced maps and database.
\end{abstract}

Keywords: visual storytelling; tangible heritage; intangible heritage; project of interaction; Cento Città d'Italia; Sonzogno

\section{Introduction}

This contribution presents an in itinere research, based on the recognition of the cultural values (signifier) of both graphic and literary images that can be found in several Italian periodical publications edited between XIX and XX centuries. Unveiling today the iconic and iconographic values, as intended in the analyzed period, shows to the contemporary reader how these images were powerful tools of communication and graphic-descriptive persuasion, aimed at building a sign and symbolic language probative of the National Unity.

The actualization of this language can be transmitted by 'systematizing' the information provided by a periodical of the late nineteenth century, in order to re-evaluate and amplify the already powerful cultural message (meaning). In this way, the image can be understood as a complex and complete form of Representation.

Many specific hints will be treated individually, to highlight their potentialities and critical issues, with the aim of making the cultural potential available to a wider audience.

Purpose of this work is to make accessible the huge corpus of images contained in the issues of Le Cento Città d'Italia supplemento mensile illustrato del Secolo (Milan, Sonzogno 1887-1902; hereinafter CC) and at the same time, to reveal interrelations between booklets and enhance them with other contextual sources [1], that would allow the user to easily visualize the 'written images', while augmenting the visual experience of the 'drawn words' [2]. 


\section{Context}

Starting from the second half of the nineteenth century, we assist to the affirmation of periodic press as a privileged medium for the wide dissemination of ideas, concepts, politics and debates $[3,4]$. Progresses in printing technology facilitated the combination of texts and images, giving a remarkable boost to the so-called 'illustrated press' and bringing the relationship between texts and images to a new degree of complexity [5]. Last, but not least, the definition of renewed interactions between 'written images' and 'drawn words' broadened the social basis of dissemination of ideas and concepts [6]. In fact, if we analyze the editorial production (periodical and not) of late nineteenth century, we can find rich sets of images of all kinds [5]. The descriptive (or even persuasive) strength of these images, to be understood as figures as well as mental projections of tangible or intangible concepts (hence representations) [7], allows an important expansion of the social utility of periodical press [8]. At the same time, it stimulates the increasing demand for 'reading' and consequent 'knowledge' [9].

Despite various approaches (visual, cultural, political) of the numerous periodicals and illustrated books of the time, as it is recalled about Emporium magazine, in the editorial newsletter that featured its upcoming release, emphasized that in the new publication "texts and figures, without being bulky to each other and vice versa, complement each other so as to provide the reader with news in the least heavier and more persuasive form", because it is often "more useful to see a well-made figure than reading a long chapter" [10] (p. 241).

An important example of this cultural policy can be found in the $C C^{\prime} s$, illustrated monthly supplement of the newspaper Il Secolo. At a first analysis of this series, the concept of cultural value of images emerges. At this point, it acquires a not negligible 'social function', while it becomes a true representation of the socio-cultural landscape of United Italy [11], by describing its local and national peculiarities [12].

Accurate analysis of this series highlights its valorization and explicit intentions of enhancing the 'national consciousness' through images. This led to create a selection of them by privileging their positive aspects, while leaving other details inside the text (as a part of the readers' oriented policy) [13].

But what does remain of this communication project of 'post Risorgimento' Italy? Is it possible to look at the descriptions of that time, today, from the point of view knowledge sharing and of substantial collective cultural growth? Can we find crumb of actuality in the literary or drawn images of the $C C$ ?

Recent studies have highlighted how the communicative power of such editorial challenges can now be interpreted as cultural operations of clear foresight [5-8], especially when the same challenges were ideally oriented to document and to popularize the huge tangible and intangible cultural heritage of the Nation [13].

Territorial dimensions of these works well express their exceptionality, even more if situated into their precise historical moment. Indeed, what is evident is the "titanic" nature of the effort [12] (p. XIX), not only cultural but also organizational one, that was necessary to the production of such documentary corpora, at a time when the accessibility of sites was still far from today's standards and the means for creating and reproducing graphic documentation were rather limited and quite expensive.

\section{Approaches and Methodologies}

Starting from the recognition of those semantic relationships which were identified in the punctual experiments so far conducted - following specific themes - $[1,11,13,14]$, we decided to work on the entire national system. It is therefore necessary to define a procedural and communicative protocol that allows the signifier to determine new meaning of the individual objects, so that it remains close to the original one [15]. In this regard, the contribution presents a first experiment, limited to a sample territory, in order to identify the classifying attributes to be extended to the entire documentary corpus. 


\subsection{References for a Meta-Project: Data and Database}

Today, there exists a variety of digitalization and popularization projects of edited materials/archival collections and similar, without forgetting the great projects of online libraries (Library of Congress, Gallica-BNF, Goggle Books among many), as well as the digitalization project of Sonzogno's works (Progetto Sonzogno, which, however, does not deal with CC) (Figure 1a) (Appendix A). Another example is the Palladio Digitale (Figure 1b): born as a one-way digitalization and preservation process of many sources connected with Palladio's work, it 'evolved' in the Palladio Library, a web-based portal which ensures the user with the possibility to access online georeferenced models of Andrea Palladio's works, directly connected with documents and sources of any kind, a sort of evolution of Palladio's graphic [16]. All of them have been a fundamental inspiration in the process of designing this communication/revaluation project (Appendix A).

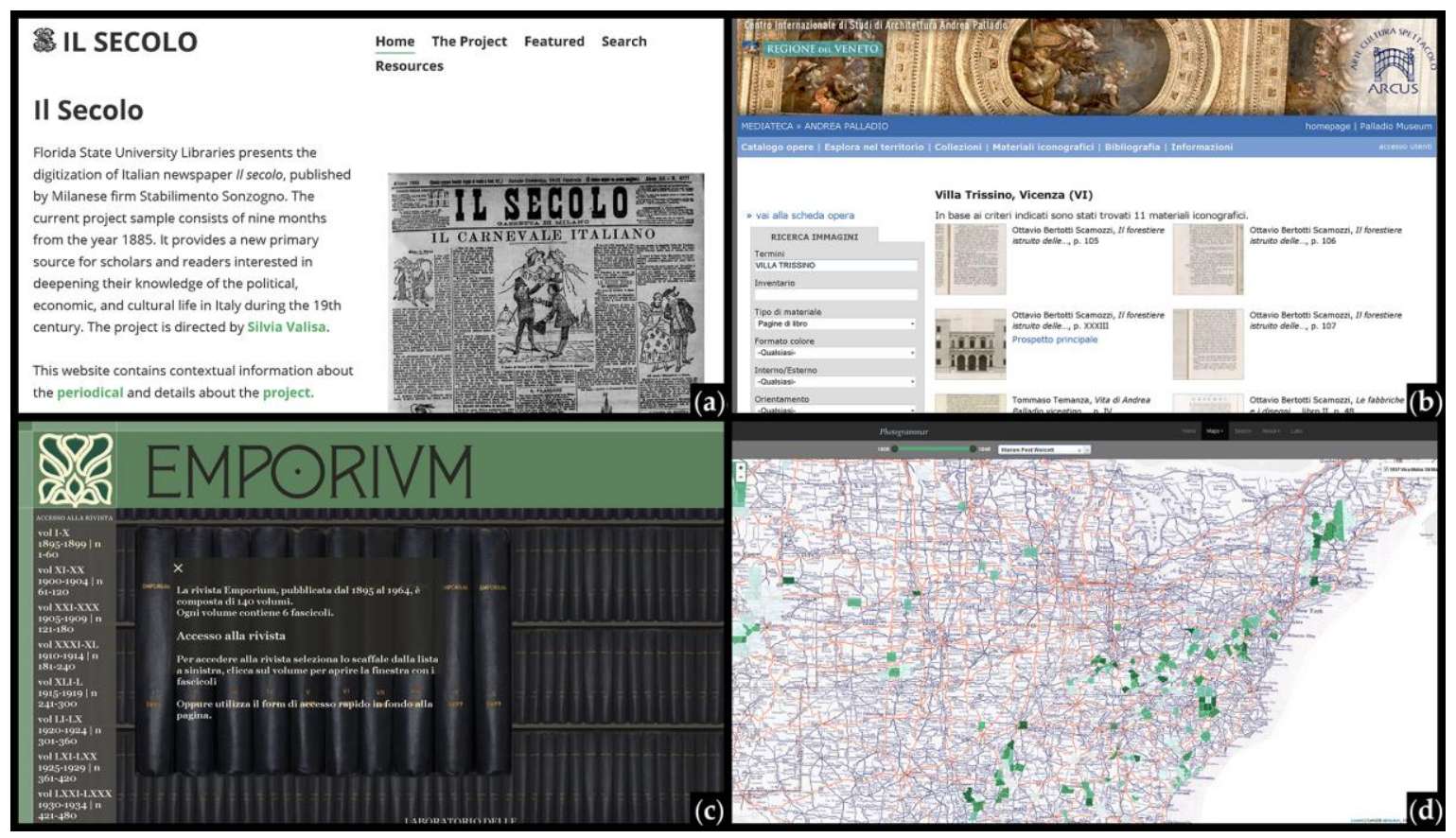

Figure 1. (a) Progetto Sonzogno, sample of the digitization of Italian newspaper Il Secolo (year 1885), edited by Sonzogno Publishing House; (b) PALLADIOLibrary Mediateca; (c) La fototeca di Emporium, online digitalization of the whole Emporium magazine; (d) Photogrammar, project of digitalization and dissemination of the FSA-OWI Collection.

The multi-disciplinary approach, typical of the polytechnic culture of survey as a complex information system [17], provided solid basis for the critical management of a variety of data in terms of purposes, including communication ones, in order to systematize its methodological approaches and its cultural and technical matrixes [18].

Aim of the present work is the management of images and texts, to make accessible and visible the 'qualitative and quantitative' relations between the means of communication and the data to be communicated, thus the structuring of database must be subject to complex indexing rules, due to their heterogeneity.

As already pointed out by the procedures adopted in other projects, a fundamental step in database structuring is the recognition of the 'subject' of images. It must be simple and as relevant as possible, to better support the next phase of research. The idea is to make extensive search of indexes of the tabbed images possible and to extend it to all fields of the catalog sheet.

In fact, it is not enough to record every single image (drawn or written) with its given title (if present), but it is necessary to connote each figure with a brief description. In this case, for example, the interactive digital reproduction of the whole corpus of the magazine Emporium (Appendix A) 
allows an advanced query for themes and subjects, as well as the possibility of 'browsing' online all the issues (Figure 1c).

\subsection{References for a Meta-Project: From Raw Data Storage to Its Visual Management}

The heterogeneity of images that can be found in $C C$ is a vital stimulus for their digitalization and sharing, not only through a database, but also by a SIT, where the process of placement 'in the space' of this information type could greatly increase its communication possibilities [19].

An interesting example of thematic and temporal georeferencing of images collection was developed in the Photogrammar project of the Yale University (Figure 1d) (Appendix A): the authors made accessible online, through a web-gis application, an entire collection of US photographs in the 1930s and 40s (of the FSA-OWI). The application can be interrogated either through visual mapping or through relational database and can be viewed on current (or of 1937) thematic cartography.

\subsection{From the Meta-Project to the Project}

In a first hypothesis of territorial, urban, architectural, human analysis, the problem is to 'go beyond' the raw data. Therefore, the importance of this process is crucial, because it can suggest critical cross-readings of the amount of collected data that are made available.

In the context of representation and architecture, the current orientation is to enrich and implement heterogeneous cartographies in order to develop digital environments for the management, visualization and sharing of georeferenced data [19-21]. Many applications are aimed at offering new, interactive, territorial perspectives, also to match differentiated information needs, focusing on the dissemination and information dimension of land-based data, as well as on the ability to involve users in discovering or re-discovering of the territorial and landscape identity, hidden in a sense or overwhelmed by the structural dynamics of contemporary living.

It emerges therefore the need to evaluate how to insert and display data on the SIT, to make clear the textual and visual references in the monographs narrations, opening the possibility of interrogating the complex editorial system from references to the territory. This can contribute to the creation of a 'Digital Cultural Network' that implements visual and interrogation tools of current and historical territory [21], and affects the appropriate choice of these tools: they require validation, which need to be shared at national level and envisages the possibility of multi-user and multi-scalar integration of the material contained in the database. The aim goes to proposing a renewed mode of interaction while overcoming the apparent constraint resulting from a synchronous reading proper to a periodical publication, in the same time enabling the raw data to be accessed, respecting its cultural value.

Therefore, to create a SIT of the CC, it is important to remember that:

"The geographic component of cultural heritage information makes a leap of quality into the systems of knowledge organization, as an indispensable background for any instrument of knowledge, analysis, intervention. In this perspective, geographic information systems allow to consider the cultural heritage in its entirety, entrusting the new role of systemic cultural good to the natural and anthropic landscape, an expression of the whole system of relationship between the individual goods and between them and the context itself" [19] (p. 241).

This highlights how the images-written and drawn-can gain an important surplus value if correlated with the geographic information body, especially if they are inserted into a system of "qualitative and quantitative" relations between the media and the set of data to be communicated, allowing to link each single significant element to the cultural heritage totality, properly implementing what is desired by the European Landscape Convention (2000).

The temporal shift of the analyzed source, with respect to the consultation environment - in its meaning of (virtual) place and (de-contextualized) mode of use-contributes to the definition of an organized layered structure that allows the management of heterogeneous information that can be displayed or showed on different media, to enhance the relationship between past representation and present representation of the (same) object. The creation of a SIT, therefore, puts in place the need to 
define the basic mapping supporting the rough display of available data. In this case, the problem arises with a twofold declination: in fact, it is necessary to be able to relate the same data to one or more media coeval with the data, for the correct philological definition of the above-mentioned relationships. At the same time, it becomes necessary to view data on a contemporary cartography, easily accessible to a generalist user.

For the visual base (raster) of the SIT, we opted for the use of heterogeneous cartography, suitable for managing the multiplicity of contents in the database. Among the many possible options, the following were selected:

(a) IGMI (Italian Military Geographic Institute) 250 Series-Italian Regions (scale 1:250.000) WGS 84 geographic referenced, which allow the entire territory to be surveyed and to propose a double synchronous and diachronic reading.

(b) IGMI (historical maps), sheet of Carta d'Italia, 1884 (Maps of Italy, scale 1:500.000), referring to the territory under consideration. As soon as this is a historical cartography made available in digital format, its potential lies in the possibility of displaying data referring to the geographical situation of the Kingdom of Italy as represented in the same years of publication of the CC.

(c) Carta delle strade ferrate italiane al 1o aprile 1889 (Italian Railways Chart on 1 April 1889, published for the care of the R. Ispettorate Generale delle Ferrate by the Italian Geographic Institute, scale 1:1.500.000). This chart, as already pointed out in a previous work [13], can be of great interest as the graphic information contained in the CC can be related, (since many descriptions have explicit references) to the logistic system of that time in Italy.

\subsection{Territorial Sample}

It can be useful to briefly investigate the role of the territorial and administrative singularities of the post-unitary Italian Provinces (formally established following Editto albertino $\mathrm{N}^{\circ} 659$ of 27 November 1847 and thus 'constitutionally' guaranteed by the Albertinus of the following year), among the criteria for the sample definition. Provinces were not historically based on the definition of precise grouping criteria of territorial units, but generated by groups of heterogeneous territories [22] (pp. 69-71). This administrative configuration of the Italian territory, as it was on the late nineteenth and early twentieth centuries, allows us to identify in the actual territory of Piedmont, more specifically in the Province of Turin, the sample on which to apply specific research addresses. In this way, we have defined a set of heterogeneous and significant elements that can be crossinterrogated. Indeed, if it is possible to argue that "Piedmont made Italy, then [...] also that Italy made Piedmont, moral and territorial heir of the Savoy state" [23] (p. 40), it becomes almost impossible not to recognize the important role that the first capital of the Kingdom, Turin, in its civic and provincial dimension, played in the political, social and economic landscape of both the Savoy State and the Italian State [24,25]. Therefore, we took the Province of Turin, as it was composed between 1887 and 1902, was taken as a territorial reference for our experimentation. In fact, the provincial sphere represented the main geographic-administrative context of both the ancient duchy of Savoy and the newborn Kingdom of Italy, and so it remained until the establishment of Regions, in 1948 [23]. We used eight booklets for the experimentation: Torino (1887) [26], Aosta e la sua valle (1889) [27], Pinerolo (1892) [28], Chieri (1895) [29], Chivasso e dintorni (1899) [30], Ivrea e il Canavese (1899) [31], Susa e dintorni (1902) [32], Torino nuova (1902) [33].

\section{Analysis and First Outcomes}

Our analysis considers: physical dimensions of figures, type and number of images per issue, connections between descriptive texts and figures, captions. For example, we show the report of images inserted in Torino Nuova (Table 1).

The sample of the eight analysed issues, allows to highlight some characteristics related to the complete work (Table 2). The 60 pages $(8 \times 7+4 \times 1)$ deliver a total of 229 images, to be divided in: 8 big images in the first pages, 55 in texts pages and 166 in only images pages. 
It might be interesting to note that the most inaccessible location, Valle d'Aosta, was described with the biggest number of images per issue, 52. This might suggest us to critically check other issues related to mountainous territory.

Table 1. Images in Torino Nuova [33].

\begin{tabular}{|c|c|c|c|c|c|c|c|c|}
\hline \multirow[b]{2}{*}{$\mathbf{n}^{\circ}$} & \multirow{2}{*}{$\begin{array}{l}\text { Image } \\
\text { Name }\end{array}$} & \multirow[b]{2}{*}{ p. } & \multicolumn{2}{|c|}{ Dimensions (mm) * } & \multicolumn{3}{|c|}{ Type } & \multirow[t]{2}{*}{ Caption ** } \\
\hline & & & Base & Height & $\begin{array}{c}\text { in } \\
\text { Text }\end{array}$ & $\begin{array}{c}\text { in Text } \\
\text { Page }\end{array}$ & $\begin{array}{c}\text { in Only } \\
\text { Images Page }\end{array}$ & \\
\hline 1 & MONUMENTO AL PRINCIPE AMEDEO & 73 & 247 & 287 & & $X$ & & Yes \\
\hline 2 & $\begin{array}{l}\text { Cappella del Santo Sudario nella cattedrale di } \\
\text { San Giovanni }\end{array}$ & 74 & 59 & 72 & $\mathrm{x}$ & & & Yes \\
\hline 3 & Maschio della Cittadella & 74 & 59 & 41 & $\mathrm{X}$ & & & Yes \\
\hline 4 & Palazzo della Banca Commerciale Italiana & 75 & 88 & 73 & $X$ & & & Yes \\
\hline 5 & Tempio Crematorio & 75 & 59 & 44 & $\mathrm{X}$ & & & Yes \\
\hline 6 & Monumento a G. B. Bottero & 75 & 59 & 73 & $\mathrm{X}$ & & & Yes \\
\hline 7 & Gustavo Modena & 75 & 35 & 59 & $\mathrm{X}$ & & & Yes \\
\hline 8 & Monumento a Benedetto Brin & 75 & 59 & 73 & $\mathrm{x}$ & & & Yes \\
\hline 9 & Monumento a Vittorio Emanuele & 76 & 124 & 149 & & & $\mathrm{X}$ & Yes \\
\hline 10 & Monumento a Giuseppe Garibaldi & 76 & 125 & 149 & & & $\mathrm{X}$ & Yes \\
\hline 11 & Via Pietro Micca & 76 & 83 & 98 & & & $\mathrm{X}$ & Yes \\
\hline 12 & Moumento al generale Alfonso La Marmora & 76 & 74 & 99 & & & $\mathrm{X}$ & Yes \\
\hline 13 & Via Quattro Marzo & 76 & 84 & 99 & & & $\mathrm{X}$ & Yes \\
\hline 14 & $\begin{array}{c}\text { Monumento al generale Carlo Nicolis di } \\
\text { Robilant }\end{array}$ & 76 & 60 & 80 & & & $\mathrm{X}$ & Yes \\
\hline 15 & Ricordo di Re Umberto a Superga & 76 & 60 & 80 & & & $\mathrm{X}$ & Yes \\
\hline 16 & Monumento della Crimea & 76 & 60 & 80 & & & $\mathrm{X}$ & Yes \\
\hline 17 & Monumento a Galileo Ferraris & 76 & 60 & 80 & & & $\mathrm{X}$ & Yes \\
\hline
\end{tabular}

Table 2. Analyzed issues: images data summary.

\begin{tabular}{ccccccccccc}
\hline & \multicolumn{1}{c}{ Issue } & \multicolumn{1}{c}{ Images } \\
\hline Title & Vol. & Date & $\mathbf{n}$ & $\mathbf{p p}$ & $\mathbf{p p ~ n}$ & $\begin{array}{c}\text { in } \\
\text { Text }\end{array}$ & $\begin{array}{c}\text { In Text } \\
\text { Page }\end{array}$ & $\begin{array}{c}\text { in Only } \\
\text { Images Page }\end{array}$ & $\begin{array}{c}\text { w/o } \\
\text { Caption }\end{array}$ & $\begin{array}{c}\text { Per } \\
\text { Issue }\end{array}$ \\
\hline TORINO & I & 25 August 1887 & 8 & $57-64$ & 8 & 8 & 1 & 25 & $7^{*}$ & $\mathbf{3 4}$ \\
\hline $\begin{array}{c}\text { AOSTA E LA } \\
\text { SUA VALLE }\end{array}$ & III & 25 January 1889 & 25 & $1-8$ & 8 & 11 & 1 & 40 & 0 & $\mathbf{5 2}$ \\
\hline PINEROLO & V & 25 March 1891 & 51 & $17-24$ & 8 & 5 & 1 & 19 & 0 & $\mathbf{2 5}$ \\
\hline CHIERI & IX & 31 December 1895 & 108 & $89-96$ & 8 & 7 & 1 & 16 & 2 & $\mathbf{2 4}$ \\
\hline $\begin{array}{c}\text { CHIVASSO E } \\
\text { DINTORNI }\end{array}$ & XIII & 31 January 1899 & 145 & $1-8$ & 8 & 4 & 1 & 18 & 0 & $\mathbf{2 3}$ \\
\hline $\begin{array}{c}\text { IVREA E IL } \\
\text { CANAVESE }\end{array}$ & XIII & 31 August 1899 & 152 & $57-64$ & 8 & 5 & 1 & 17 & 0 & $\mathbf{2 3}$ \\
\hline $\begin{array}{c}\text { SUSA E } \\
\text { DINTORNI }\end{array}$ & XVI & 31 May 1902 & 185 & $33-40$ & 8 & 8 & 1 & 22 & 0 & $\mathbf{3 1}$ \\
\hline $\begin{array}{c}\text { TORINO } \\
\text { NUOVA }\end{array}$ & XVI & 31 October 1902 & 190 & $73-76$ & 4 & 7 & 1 ** & 9 & 0 & $\mathbf{1 7}$ \\
\hline
\end{tabular}

* All these images are somehow described in the text; ${ }^{* *}$ The image is in the first page which doesn't present lines of text.

As a previous work already stated [14], we can find 'three 'macro-typologies' of different booklets' 'head titling', as well as two different pagination models used for the individual pages, here there are two types of the first of the issue. In fact, if the headline containing the editorial data (date, issue number, etc.) is excluded, the first page can be characterized by: text with image (more or less large, always arranged on 4 columns horizontally) or a full-page image.

In turn, the illustrations of the first page can be subdivided according to the different reported representations scales: territorial (panorama or view), urban (urban or urban view), architectural (single building), detail (single monument) (Figure 2). In the monographs, there are several representation scales that represent different declinations of the cross-narrative sequence in the 
different monographs. It is also interesting to underline how similar images, such as images in texts columns, can be inserted and described with captions (Figure 3a) or without captions (Figure 3b). In the second case, figure description can be found right in the circumscribing textual descriptions, and constitutes one of that written images already recalled, where the text completes the figure.

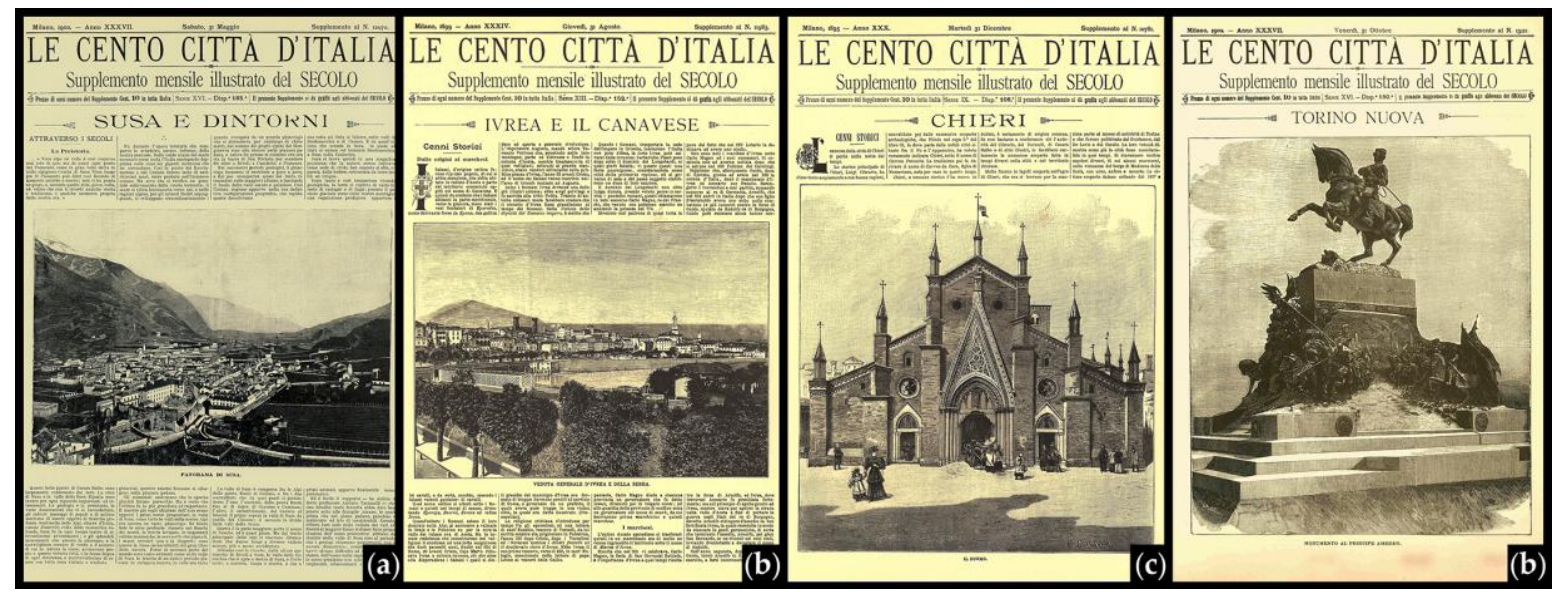

Figure 2. Examples of different representation scales of the images in the first page: (a) territorial; (b) urban; (c) architectural; (d) detail.

“Urrah! è il grido di battaglia dell'antico bersagliere piemontese che, caricando alla bajonetta si slancia nella mischia a cercarvi una morte gloriosa in difesa della patria, e facendo pagar cara ai nemici la propria vita. Guardando quella statua dalla quale traspare un sublime eroismo, ci sentiamo commossi in petto a palpitare il cuore, ci sentiamo orgogliosi di essere italiani, figli di questa gloriosa nazione che sa insipirare $a^{\prime}$ suoi soldati tante virtù e tanta abnegazione. E nella nostra muta ammirazione, la mente ricorre ai deserti africani. -Ecco, pensiamo come sono caduti i nostri prodi soldati a Dogali e Saati, caricando alla bajonetta e stringendo l'arma fino all'ultimo respiro! L'Urrah è opera del giovane e simpatico ufficiale Giorgio Ceragioli, sottotenente del $5^{\circ}$ bersaglieri, che la eseguì in gesso nel termine di soli dodici giorni, l'anno scorso per l'anniversario della fondazione del corpo dei bersaglieri. Ora per ordine del Ministero della Guerra la statua viene fusa in bronzo al nostro arsenale: e verrà collocata in qualche museo". [26] (p. 59).

In other cases, the written images act as a figure substitute, as it occurs in the case of Aosta, which will be discussed in the next lines:

"Oltrepassiamo Ivrea bella e aggraziata, che avremo tempo di visitare un'altra volta e, dopo l'oscuritàa forzosa procurataci da una galleria di 1109 metri, usciamo collo sguardo rallegrato dalla amena pianura di Montalto-Ivrea, il cui castello superbo, torreggia a destra" [27] (p. 1).

A first thematic analysis can be carried out, for example, on the issue Aosta e la sua valle (Aosta and its valley) (1889) [27], whose structure reveals some peculiar characters of the whole work (Figure 4).

The issue opens with a General View of the City and the surrounding landscape, but what still impresses today's reader is the fact that the description begins with the story of the train journey that a hypothetical traveler must undertake to reach Aosta from Chivasso, passing through Ivrea. Moreover, this aspect of the description, which intersects more places described in different issues of the $C C$, creates a strong system of cross-references in between the issues themselves:

"E avanti, avanti, attraverso Borgofranco dalla cantine-caverne e dalla benefica acqua arsenicale. E sfilano le stazioni di Tavagnasco, Settimo Vittone, Quincinetto e arriviamo a Pont-Saint Martin che appartenne per molto tempo al Circondario d'Ivrea, ed ora forma il primo comune della Valle d'Aosta" [27] (p. 1). 


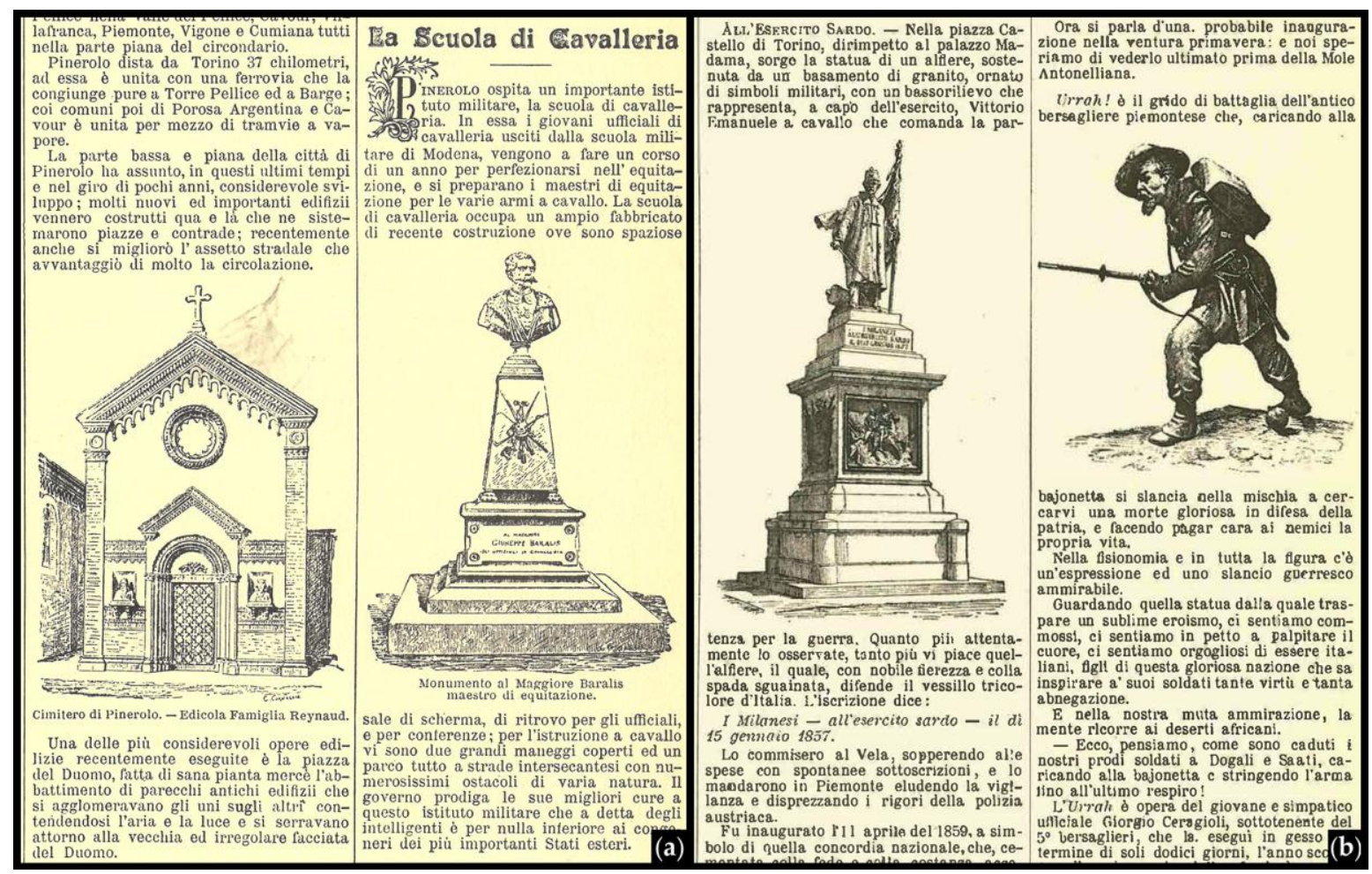

Figure 3. Examples of in text images (a) with captions [28] (p. 19); (b) without captions [26] (p. 59).

This kind of lines are part of the analysis, so we need to understand if they can be a new category of data, where textual descriptions lead the reader to visualize an image (a written image).

Not surprisingly, meticulous attention to technical signs of the technique, as already pointed out [13], as well as the presentation of military forts the traveler encounters during his journey. The description of castles that surround the Canavese and Valle d'Aosta gives a way to include in the text a report on the castle of Montaldo Dora, which will only be visually represented ten years later by an image (no longer commented) inserted in the issue about Ivrea e il Canavese (1899) [31] (p. 64). Another interesting narrative aspect emerges from the limited weight reserved to the city description of Aosta in the relative booklet. Its title is in fact characterized by great importance attribuited to the Valley and in this case, the City itself occupies only about $20 \%$ of the text. In contrast, in the monograph of Susa e dintorni (Susa and the surrounding area) (1902) [32], Susa city occupies about $80 \%$ of the text, while the remaining $20 \%$ is dedicated to its 'surrounding area', similarly to the above-mentioned case of Ivrea e il Canavese.

This analysis reflects how the title of the single issue is harbinger of its content as, in a sense, it 'metalinguistically' suggests them to the reader. 


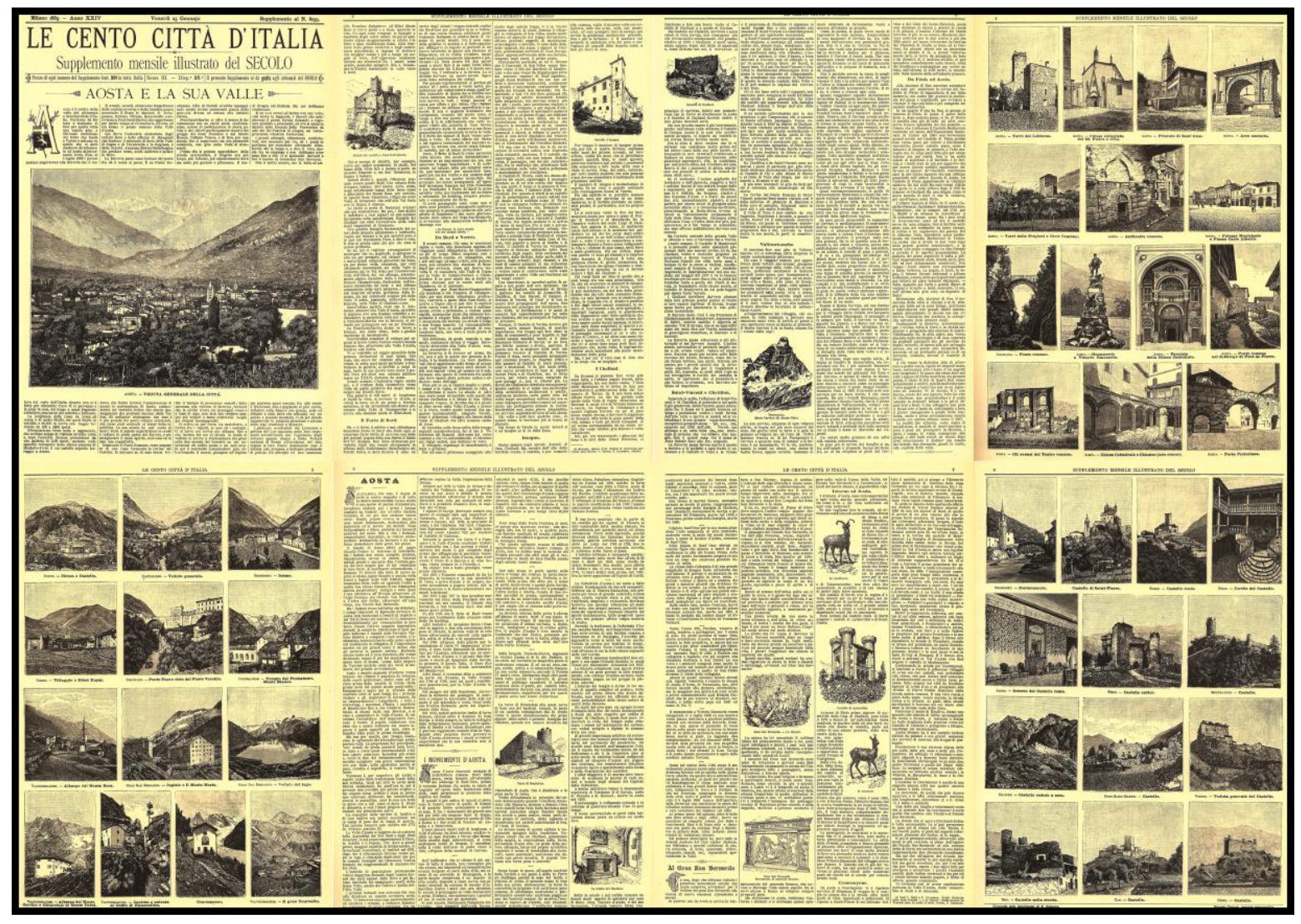

Figure 4. Aosta e la sua valle issue [27].

\section{Conclusions}

In order to provide a comparison between the forms of representing, doing and organizing the urban culture at the time of globalization - between different languages, knowledge and cultures in an interdisciplinary perspective-the project works on those "cognitive mechanisms of communication" that filter, group and organize data from the outside world into "information blocks destined to one side of the memory store and on the other to stimulate the user's response" [34].

The first results of the project allow us to conjecture that the narration (and therefore discovery) of the Country System follows precise guidelines, almost completely overlapping the national transport system, both on long and short-distance. Thus, the data visualization available on thematic maps allows an overall and punctual analysis.

"If [in the Emporium magazine] there is a thread linking 'isolated' places to 'city' places, this one is the 'idea of place' as a sediment of stratified testimonies, as a 'place of memory', often of a menaced memory". At the same time, the editorial effort to illustrate these places, more or less dispersed in the national territory, is transformed, perhaps without a specific awareness, into an important conservation work, or even "civilian reporting activity" capable of sensitizing public opinion in a decisive fashion [10] (p. 262).

Hence, a CC specific SIT can support an innovative and implementable critical analysis, offering new reading keys to the user. It would in fact go beyond the printed sequence, privileging the 'digital accessibility' of the site, stimulating the transition from a linear narrative approach, related to the reading of individual issues, to an interactive consequential narration. This way we provide the structure for navigating through the contents of database tabs and different searching keys. The results highlight the possibility of making available to interested scholars and general public a structured set of freely accessible sources, pointing out a series of interactions/questions to assess the accessibility of the described site/territory and recognizing to these sources the value of testimony and documentation, that can be critically analysed, in view of their great cultural importance. 
Author Contributions: As soon as the project is mutually leaded, the authorship is equally shared by the authors.

Conflicts of Interest: The authors declare no conflict of interest.

\section{Appendix A}

Online projects cited in Sections 3.1 and 3.2. Last access 24 July 2017.

Progetto Sonzogno: <www.progettosonzogno.org $>$; $<$ http://ilsecolo.lib.fsu.edu/>.

PALLADIOlibrary: <https://mediateca.palladiomuseum.org/palladio/opere.php >.

La fototeca di Emporium: <www.artivisive.sns.it/fototeca $>$.

Photogrammar: <http://digitalhumanities.yale.edu/projects/photogrammar $>$.

\section{References}

1. Marchis, E.T.C.; Pavignano, M.; Zich, U. The fortifications on a Citizen scale. Analysis of visual storytelling of Ligurian cities in "Supplemento mensile illustrato del SECOLO" (1887-1902). In Defensive Architecture of the Mediterranean XV to XVIII Centuries; Verdiani, G., Ed.; Didapress: Firenze, Italy, 2016; pp. 405-412, ISBN 9788896080603.

2. Conti, S. La rappresentazione, ovvero: Geografie dello sguardo. In Riflessi Italiani: L'identità di un Paese Nella Rappresentazione del suo Territorio; Conti, S., Ed.; TCI: Milano, Italy, 2004; pp. 8-11, ISBN 9788836531295.

3. Gigli Marchetti, A. Le nuove dimensioni dell'impresa editoriale. In Storia Dell'editoria Nell'italia Contemporanea; Turi, G., Ed.; Giunti: Firenze, Italy, 1997; pp. 113-164, ISBN 8809212363.

4. Pallottino, P. Il mondo a dispense. In Storia Dell'illustrazione Italiana. Cinque Secoli di Immagini Prodotte; Pallottino, P., Ed.; Uscher Arte: Firenze, Italy, 2010; pp. 235-256, ISBN 9788895065465.

5. Bacci, G. Le illustrazioni in Italia tra Otto e Novecento: Libri a Figure, Dinamiche Culturali e Visive; Olschki: Firenze, Italy, 2009; ISBN 9788822259301.

6. Forgnacs, D. L'industrializzazione della cultura italiana (1880-2000); Il Mulino: Bologna, Italy, 2000.

7. Gay, F. Architettura in quanto immagine: Spazio contro tempo. In Idee per la Rappresentazione 7-Visualità; Atti del Seminario di Studi; Belardi, P., Ed.; Artegrafica: Roma, Italy, 2015; pp. 219-237, ISBN 9788890458590.

8. Valisa, S. Casa editrice Sonzogno: Mediazione culturale, circuiti del sapere ed innovazione tecnologica nell'Italia unificata (1861-1900). In The Printed Media in Fin-de-Siècle Italy; Hallamore Caesar, A., Romani, G., Burns, J., Eds.; Legenda: London, UK, 2011; pp. 90-106, ISBN 9781906540746.

9. Bacci, G. 'Parole e figure': Fotografia e testo tra le pagine di "Emporium" e "Il Secolo XX". In Emporium. Parole e Figure tra il 1895 e il 1964; Bacci, G., Ferretti, M., Fileti Mazzia, M., Eds.; Edizioni della Normale: Pisa, Italy, 2009; pp. 95-153, ISBN 9788876423642.

10. Levi, D. Memoria ed immagine del territorio fra testimonianze artistiche e bellezze naturali. In Emporium. Parole e Figure tra il 1895 e il 1964; Bacci, G., Ferretti, M., Fileti Mazzia, M., Eds.; Edizioni della Normale: Pisa, Italy, 2009; pp. 235-270, ISBN 9788876423642.

11. Pavignano, M.; Zich, U. Different matrixes of Sicilian landscapes in Le Cento Città d'Italia. Social identity, cultural landscape and collective consciousness in-between texts and images. In Putting Tradition into Practice: Heritage, Place and Design, Proceedings of 5th INTBAU International Annual Event, Milano, Italy, 5-6 July 2017; Amoruso, G., Ed.; Lecture Notes in Civil Engineering; Springer Intl Pub. AG: Cham, Switzerland, 2017; Volume 3, pp. 823-833.

12. Bellocchi, U. Saggio introduttivo. In Le Cento Città d'Italia. Supplementi Mensili Illustrati de Il Secolo. Milano, Edoardo Sonzogno Editore, 1887-1902; Intl Ad. Company: Bologna, Italy; pp. VII-XX, 1983

13. Pavignano, M.; Zich, U. La narrazione dei paesaggi nell'Italia post-unitaria: Sonzogno divulgatore. Narration of the post-unitary Italian landscape: Sonzogno popularizer. In Delli Aspetti de Paesi. Vecchi e Nuovi Media per L'IMMAGINE del Paesaggio; Berrino, A., Buccaro, A., Eds.; CIRICE: Napoli, Italy, 2016; pp. 1153-1162, ISBN 9788899930004.

14. Zich, U.; Comollo, U.; Pavignano, M. Turin in "Le Cento Città d'Italia": Sonzogno publisher representing and narrating a reality in transformation between the XIX and XX centuries. In Drawing and City/Culture, Art, Science, Information; $37^{\circ}$ Convegno Internazionale dei Docenti della Rappresentazione; Marotta, A., Novello, G., Eds.; Gangemi: Roma, Italy, 2015; pp. 1203-1212, ISBN 9788849231243.

15. Marotta, A. Metodologie di analisi per l'architettura: Il Rilievo come conoscenza complessa in forma di database. In Sistemi Informativi Integrati per la Tutela, la Conservazione e la Valorizzazione del Patrimonio 
Architettonico e Urbano; Brusaporci, S., Brusaporci, S., Eds.; Gangemi: Roma, Italy, 2010; pp. 69-141, ISBN 9788849218602.

16. Beltramini, G.; Gaiani, M. Dalla grammatica palladiana alla Palladio Library: Piccola storia del sistema comunicativo-informativo palladiano. In Palladio Lab-Architetture Palladiane Indagate con Tecnologie Digitali; Beltramini, G., Gaiani, M., Eds.; CISA AP: Vicenza, Italy, 2012; pp. 9-17, ISBN 9788884180971.

17. Boido, M.C. Il processo di conoscenza tra storia e rilievo. In Rilievo Urbano. Conoscenza e Rappresentazione Della Città Consolidata; Coppo, S., Boido, M.C., Eds.; Alinea: Firenze, Italy, 2010; pp. 50-79, ISBN 9788860555366.

18. Marotta, A.; De Berdardi, M.L.; Bailo, M. La conoscenza di architettura, città e paesaggio: "Il Progetto Logico di Rilievo" in una sperimentazione metodologica. Disegnarecon 2008, 1, 1.2-1.13.

19. Ippoliti, E. Mappe, modelli e tecnologie innovative per conoscere, valorizzare e condividere il patrimonio urbano. Indagini sperimentali di sistemi integrati sul Piceno. In Sistemi Informativi Integrati per la Tutela, la Conservazione e la Valorizzazione del Patrimonio Architettonico e Urbano; Brusaporci, S., Ed.; Gangemi: Roma, Italy, 2010; pp. 240-251, ISBN 9788849218602.

20. Ardissono, L.; Lucenteforte, M.; Savoca, A.; Voghera, A. GroupCollaborate2: Interactive Community Mapping. In UMAP 2014 Extended Proceedings; Cantador, I., Chi, M., Eds.; RWTH: Aachen, Germany, 2014; pp. 45-48, ISSN 1613-0073-2014.

21. Fatta, F.; Bassetta, M.; Mant, M. Reggio Calabria museo di se stessa. Progetto per un museo interattivo della città. Reggio Calabria, Museum of itself. Project for an interactive Musem of the City. Disegnarecon 2016, 9 , 5.1-5.16. ISSN 1828-5961.

22. Gambi, L.; Merloni, F. (Eds.) Amministrazioni Pubbliche e Territori in Italia; Il Mulino: Bologna, Italy, 1995; ISBN 8815050892.

23. Merlotti, A. Il Piemonte. Le evoluzioni di un'identità da Stato sabaudo a regione italiana. Stud. Piedmont. 2011, 40, 403-412.

24. Castronovo, V. (Ed.) Storia Delle Regioni Italiane Dall'unità a Oggi. I. Il Piemonte; Einaudi: Torino, Italy, 1977.

25. Salviati, M.; Sciolla, L. (Eds.) L'Italia e le sue Regioni. Istituzioni; Istituto Della Enciclopedia Italiana G. Treccani: Roma, Italy, 2015; Volume III, ISBN 9788812005314.

26. Torino. Le Cento Città d'Italia. Supplemento Mensile Illustrato del Secolo 1887, I, 57-64.

27. Aosta e la sua Valle. Le Cento Città d'Italia. Supplemento Mensile Illustrato del Secolo 1889, III, 1-8.

28. Pinerolo. Le Cento Città d'Italia. Supplemento Mensile Illustrato del Secolo 1891, V, 17-24.

29. Chieri. Le Cento Città d'Italia. Supplemento Mensile Illustrato del Secolo 1895, IX, 89-96.

30. Chivasso e Dintorni. Le Cento Città d'Italia. Supplemento Mensile Illustrato del Secolo 1899, XIII, 1-8.

31. Ivrea e il Canavese. Le Cento Città d'Italia. Supplemento Mensile Illustrato del Secolo 1899, XIII, 57-64.

32. Susa e Dintorni. Le Cento Città d'Italia. Supplemento Mensile Illustrato del Secolo 1902, XVI, 33-40.

33. Torino Nuova. Le Cento Città d'Italia. Supplemento Mensile Illustrato del Secolo 1902, XVI, 73-76.

34. Appiano, A. Manuale di Immagine. Intelligenza Percettiva, Creatività, Progetto; Meltemi: Roma, Italy, 1998; ISBN 9788869163791.

(C) 2017 by the authors. Licensee MDPI, Basel, Switzerland. This article is an open access article distributed under the terms and conditions of the Creative Commons Attribution (CC BY) license (http://creativecommons.org/licenses/by/4.0/). 